\title{
Erratum: Ethics in compulsory education - Human dignity, rights and social justice in five contexts
}

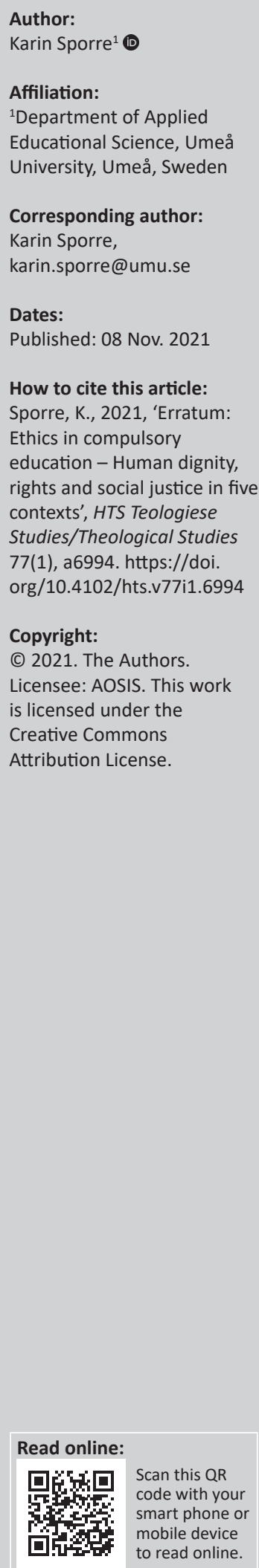

Scan this QR code with your smart phone or mobile device to read online.

In the version of the article initially published, Sporre, K., 2020, 'Ethics in compulsory education Human dignity, rights and social justice in five contexts', HTS Teologiese Studies/Theological Studies 76(1), a5821. https://doi.org/10.4102/hts.v76i1.5821, on page 5, the paragraph detailing the research question was incorrectly written as 'What ethical competence for compulsory schooling do curricula from Namibia, South Africa, California in the USA, Québec in Canada and Sweden prescribe regarding how social justice is expressed through aspects such as class, gender and race, as well as human dignity and human rights?'.

The correct wording is 'The research question of this study is as follows: what ethical competence for compulsory schooling do curricula from Namibia, South Africa, California in the USA, Québec in Canada and Sweden prescribe regarding how social justice is expressed through aspects such as class, gender and race, as well as human dignity and human rights?'.

In addition, in the version of the article initially published, on page 2 and page 7 , a reference is incorrectly cited as 'Sporre et al. in press'. The correct citation for this reference on page 2 and page 7 is 'Sporre et al. 2020'.

These corrections do not alter the study's findings of significance or overall interpretation of the study's results. The publisher apologises for any inconvenience caused. 